\title{
Perlindungan Investor Asing dalam Kegiatan Penanaman Modal Asing dan Implikasinya Terhadap Negara
}

\author{
Agung Sudjati Winata \\ Fakultas Hukum, Sekolah Tinggi Hukum Bandung, Bandung. \\ Email: agung.sudjatiwinata@gmail.com
}

Info Artikel:

| Diterima: 10 Desember 2018

| Disetujui: 29 Desember 2018

| Dipublikasikan: 31 Desember 2018

\begin{abstract}
Foreign investment is one source of funds to finance national development. Many factors are taken into consideration by foreign investors before investing in Indonesia. One of them is the legal protection that given by the state to foreign investors. From this description, problems arise including about the form of legal protection provided and the implications. This study aims to find out and analyze the legal protection of foreign investment in Indonesian law and implications itself. This research is a descriptive study, which analyzes and describes systematically, factually, and accurately the provisions relating to legal protection against foreign investment in Indonesia. Based on the results of the study, it is known that legal protection against foreign investment in Indonesian law is regulated in the Investment Law. This law has provided adequate protection for foreign investors for a variety of risks including non-commercial risks in foreign investment in Indonesia. Providing the widest opportunity for foreign investors to invest their capital in Indonesia has encouraged many foreign investors to invest in Indonesia.

Keywords: Investor, Investment, Legal Protection.
\end{abstract}

\begin{abstract}
Abstrak
Penanaman modal asing merupakan salah satu sumber dana untuk membiayai pembangunan nasional. Banyak faktor yang menjadi pertimbangan para investor asing sebelum melakukan kegiatan investasi di Indonesia. Salah satunya adalah faktor perlindungan hukum yang di berikan oleh negara terhadap investor asing. Dari uraian singkat tersebut muncul permasalahan antara lain mengenai bentuk perlindungan hukum yang diberikan dan implikasi dari perlindungan yang diberikan tersebut. Penelitian ini bertujuan untuk mengetahui dan menganalisis perlindungan hukum terhadap penanaman modal asing dalam hukum nasional Indonesia serta bagaimana implikasinya. Penelitian ini merupakan penelitian deskriptif, yaitu menganalisis dan menggambarkan secara sistematis, faktual, dan akurat ketentuan yang terkait dengan perlindungan hukum terhadap penanaman modal asing di Indonesia. Berdasarkan hasil penelitian, diketahui bahwa perlindungan hukum terhadap penanaman modal asing dalam hukum nasional Indonesia diatur dalam UU Penanaman Modal. Undang-undang ini telah memberikan perlindungan yang memadai terhadap investor asing atas berbagai risiko termasuk risiko nonkomersial dalam penanaman modal asing di Indonesia.Pemberian kesempatan yang seluas-luasnya kepada investor asing untuk menginvestasikan modalnya di Indonesia telah mendorong banyak investor asing melakukan investasi di Indonesia.
\end{abstract}

Kata Kunci :Investor, Penanaman Modal, Perlindungan Hukum. 


\section{A. PENDAHULUAN}

Sumber utama dana pembangunan nasional di Indonesia adalah dana dalam negeri. Namun demikian, jumlah dana dalam negeri yang tersedia sangat terbatas, sehingga pemerintah memanfaatkan dana dari luar negeri. Salah satu sumber dana dari luar negeri yang dapat digunakan untuk membiayai pembangunan nasional Indonesia adalah penanaman modal asing. Penanaman modal asing sebagai bentuk aliran modal mempunyai peran penting bagi pertumbuhan perekonomian suatu negara, khususnya negara berkembang. Hal ini disebabkan investor asing tidak hanya memindahkan modal barang, tetapi juga mentransfer pengetahuan dan modal sumber daya manusia. ${ }^{1}$ Bagi Indonesia dan negara-negara berkembang lainnya, penanaman modal asing mempunyai kontribusi secara langsung bagi pembangunan nasional yang telah direncanakan.

Dalam pelaksanaan kegiatan penanaman modal asing, tidak tertutup kemungkinan terjadinya sengketa antara investor asing dengan Pemerintah Indonesia. Sengketa tersebut disebabkan oleh berbagai alasan, antara lain pelanggaran kontrak penanaman modal oleh investor atau oleh pemerintah, pencabutan izin usaha penanaman modal oleh pemerintah, pelanggaran terhadap hak-hak investor yang diatur dalam UU Penanaman Modal, serta pengambilalihan atau nasionalisasi terhadap perusahaan asing.

Perlindungan atas investasi tersebut tidak terlepas dari berbagai masalah dan risiko yang dihadapi investor asing terkait dengan kegiatan penanaman modalnya di negara penerima modal. Banyak hal yang menyebabkan terjadinya risiko dalam suatu kegiatan penanaman modal asing, antara lain situasi politik serta krisis ekonomi dan moneter yang terjadi di negara penerima modal, yang mengakibatkan ditundanya

1 Hans-Rimbert Hemmer et al., tanpa tahun, Negara Berkembang dalam Proses Globalisasi: Untung atau Buntung? (Jakarta: Konrad Adenauer Stiftung - Jakarta Office), hlm. 11. beberapa proyek investasi yang telah disepakati dengan investor asing.

Upaya pemberian jaminan dalam kegiatan penanaman modal asing di Indonesia sebagai bentuk perlindungan terhadap investor asing, tentu saja diharapkan dapat meningkatkan arus investasi asing ke Indonesia. Tidak dapat diingkari bahwa Indonesia sangat membutuhkan kehadiran investor asing. Pada gilirannya, dengan meningkatnya penanaman modal asing, maka akan memberikan kontribusi yang lebih besar bagi perekonomian Indonesia.

Berdasarkan latar belakang tersebut, muncul permasalahan yaitu bagaimana perlindungan hukum terhadap investor asing di Indonesia dan implikasinya ? Penelitian ini bertujuan untuk mengetahui perlindungan hukum terhadap investor asing dan implikasi dari perlindungan investor asing terhadap negara.

\section{B. METODE PENELITIAN}

Sesuai dengan masalah yang diteliti, penelitian ini merupakan penelitian hukum normatif. Untuk mencari dan menemukan jawaban atas masalah dalam penelitian ini, digunakan pendekatan perundang-undangan (statue approach) yang terkait dengan perlindungan penanaman modal asing di Indonesia. Data yang digunakan untuk mengkaji masalah yang diteliti meliputi Undang-Undang Nomor 25 Tahun 2007 tentang Penanaman Modal dan bahan hukum primer berupa karya-karya ilmiah dan hasil penelitian para ahli hukum, khususnya yang terkait dengan penanaman modal asing. Data dikumpulkan dengan cara studi kepustakaan, kemudian dianalisis menggunakan metode normatif kualitatif.

\section{KERANGKA KONSEPTUAL}

\section{Penanaman modal asing}

Pasal 1 Angka 3 UU Nomor 25 Tahun 2007 tentang Penanaman Modal merumuskan pengertian penanaman modal asing sebagai kegiatan menanamkan modal untuk melakukan usaha di wilayah negara Republik 
Indonesia yang dilakukan oleh penanam modal asing, baik yang menggunakan modal asing sepenuhnya maupun yang berpatungan dengan penanam modal dalam negeri.Kegiatan penanaman modal merupakan kegiatan untuk memasukkan modal atau investasi dengan tujuan untuk melakukan suatu kegiatan usaha. Kegiatan penanaman modal ini dilakukan oleh penanam modal asing, baik yang seluruh modalnya dimiliki pihak asing maupun yang modalnya merupakan patungan antara pihak asing dan pihak domestik. Penanaman modal asing melalui usaha patungan merupakan modal asing yang bekerja sama dengan penanam modal domestik, dengan ketentuan pihak asing maksimal menguasai $95 \%$ modal, sedangkan investor domestik memiliki minimal $5 \%$ modal. $^{2}$

Selain pengertian di atas, M. Sornarajah juga memberikan defenisi tentang penanaman modal asing sebagai transfer of tangible or intangible assets from one country to another for the purpose of use in the country to generate wealth under the total or partial control of the owner of the assets. ${ }^{3}$ Secara harfiah, definisi tadi bermakna bahwa penanaman modal asing merupakan transfer modal, baik yang nyata maupun yang tidak, dari suatu negara ke negara lain, dengan tujuan untuk digunakan di negara tersebut agar menghasilkan keuntungan di bawah pengawasan dari pemilik modal, baik secara keseluruhan maupun sebagian.

Selain pengertian penanaman modal asing, dalam Pasal 1 Angka 8 UU Penanaman Modal juga dirumuskan pengertian modal asing, yaitu:

"Modal asing adalah modal yang dimiliki oleh negara asing, perseorangan warga negara asing, badan usaha asing, badan hukum asing, dan/atau badan hukum

\footnotetext{
2 Salim HS dan Budi Sutrisno, Hukum Investasi di Indonesia (Jakarta: RajaGrafindo Persada, 2008), hlm. 148-149.

3 M. Sornarajah dalam Ibid., hlm. 149.
}

Indonesia yang sebagian atau seluruh modalnya dimiliki oleh pihak asing."

Berdasarkan pengertian di atas, diketahui bahwa pemilik modal asing dapat terdiri dari beberapa pihak, yaitu:

1. Negara asing;

2. Perseorangan warga negara asing;

3. Badan usaha asing;

4. Badan hukum asing; dan

5. Badan hukum Indonesia yang sebagian atau seluruh modalnya dimiliki oleh pihak asing.

\section{Teori Tujuan Hukum}

Tujuan pembentukan hukum dapat dirumuskan dalam berbagai sudut pandang. Terkait dengan hal tersebut, Notohamidjojo mengemukakan bahwa pada intinya tujuan hukum adalah untuk melindungi hak dan kewajiban manusia dalam masyarakat dan melindungi lembaga-lembaga sosial dalam masyarakat (dalam arti luas, yang mencakup lembaga-lembaga sosial di bidang politik, sosial, ekonomi, dan kebudayaan) atas dasar keadilan untuk mencapai keseimbangan serta damai dan kesejahteraan umum (bonum commune $).{ }^{4}$ Dari pandangan tersebut, terlihat bahwa tujuan hukum pada intinya adalah untuk memberikan perlindungan terhadap hak dan kewajiban. Perlindungan terhadap hak dan kewajiban berlaku juga dalam setiap transaksi bisnis, termasuk dalam penanaman modal asing.

Dalam bisnis internasional, untuk menganalisis fenomena transaksi ekonomi antarnegara, salah satunya menggunakan pendekatan yang berorientasi pada prinsip keadilan. Pendekatan ini sangat dipengaruhi oleh tokoh-tokoh teori keadilan, seperti John Rawls dan Robert Nozick. ${ }^{5}$ Konsep keadilan

4 O.Notohamidjojo, Makna Negara Hukum Bagi Pembaharuan Negara dan Wibawa Hukum Bagi Pembaharuan Masjarakat di Indonesia (Djakarta: Badan Penerbit Kristen, tanpa tahun terbit), hlm. 80.

5 Bob Sugeng Hadiwinata, 2002, Politik Bisnis Internasional (Yogyakarta: Kanisius), hlm. 52. 
itu sendiri merujuk pada suatu sistem keteraturan sosial yang dapat digunakan untuk menetapkan hak dan kewajiban pihak-pihak yang terlibat dalam hubungan sosial. Prinsip keadilan sangat menjunjung tinggi integritas individu. Dalam konteks politik ekonomi, teori keadilan mencoba untuk mengukur mekanisme pasar berdasarkan prinsip-prinsip keseimbangan antara hak dan kewajiban serta penghargaan terhadap integritas individu. ${ }^{6}$

Selanjutnya, ketertiban dan keteraturan diwujudkan dalam perilaku manusia dalam kehidupan dengan sesamanya. Oleh sebab itu, diperlukan sejumlah peraturan yang mengatur perilaku manusia yang kepatuhannya tidak didasarkan pada kemauan bebas setiap manusia. Aturan-aturan bagi perilaku demikian disebut hukum, yang pelaksanaannya harus dapat dipaksakan oleh otoritas publik. Dengan demikian, dapat disimpulkan bahwa salah satu tujuan hukum adalah mengatur perilaku manusia dalam hubungan-hubungan kemasyarakatan, jika perlu dengan paksaan sehingga terwujud ketertiban dan keteraturan. $^{7}$

Tujuan lain dari hukum adalah untuk menciptakan kepastian. Kepastian hukum merupakan salah satu asas esensial dalam negara hukum. Budiono Kusumohamidjojo menyatakan bahwa kepastian hukum nyaris merupakan syarat mutlak bagi suatu negara hukum modern dan demokratis. Kepastian hukum adalah konsistensi dalam penyelenggaraan hukum. Penyelenggaraanhukum yang tidak konsisten tidak akan membuat masyarakat mau mengandalkan hukum sebagai perangkat kaidah yang mengatur kehidupan bersama. Konsistensi dalam penyelenggaraan hukum diperlukan sebagai acuan bagi perilaku manusia sehari-hari dalam berhubungan dengan manusia lainnya. ${ }^{8}$

\footnotetext{
Ibid.

B. Arief Sidharta, Filsafat Hukum Pancasila, Makalah, (Tidak dipublikasikan), hlm. 6.

8 Budiono Kusumohamidjojo, 1999, Ketertiban Yang Adil: Problematik Filsafat Hukum, Grasindo, Jakarta, hlm. 150.
}

\section{PEMBAHASAN 1. Perlindungan Hukum terhadap
Penanaman Modal Asing}

Perkembangan iklim investasi di Indonesia belum menunjukkan peningkatan atau perkembangan yang berarti walaupun pada dasarnya Indonesia mempunyai potensi yang besar untuk melakukan kegiatan investasi. Hal tersebut berkaitan dengan masalah-masalah yang masih sering dihadapi oleh investor asing dalam merealisasikan penanaman modalnya di Indonesia antara lain:

a. Infrastruktur yang masih belum memadai dan merata di seluruh Indonesia;

b. Masalah yang terkait dengan ketenagakerjaan;

c. Masalah yang terkait dengan regulasi;

d. Masalah yang terkait dengan birokrasi;

e. Masalah yang terkait dengan kualitas sumber daya manusia;

f. Masalah mekanisme penyelesaian sengketa yang kurang kredibel;

g. Adanya peraturan daerah, keputusan menteri, atau undang-undang yang turut mendistorsi kegiatan penanaman modal;

h. Masalah ketidakpastian berinvestasi;

i. Masalah kepastian hukum.

Pada dasarnya, banyak faktor yang mempengaruhi minat para investor asing untuk menginvestasikan modalnya di suatu negara. Salah satu faktor penarik (pull factors) yang ada di negara penerima modal, yaitu terkait dengan kebijakan pemberian insentif di bidang perpajakan, tersedianya infrastruktur yang memadai, serta tersedianya tenaga kerja yang terampil dan berdisiplin. Selain faktor tersebut, faktor utama yang dijadikan pertimbangan oleh para investor sebelum menanamkan modalnya adalah faktor kepastian hukum yang tentu saja terkait dengan stabilitas politik dan keamanan di negara penerima modal.Daya tarik investor asing untuk melakukan investasi di Indonesia akan sangat bergantung pada sistem hukum yang diterapkan. Sistem hukum itu harus mampu menciptakan kepastian, keadilan, dan efisiensi. 
Upaya-upaya yang dibangun untuk menarik investasi di Indonesia tidak diikuti dengan jaminan kepastian hukum bagi kegiatan investasi. Persoalan ini mengakibatkan para investor enggan untuk menanamkan modalnya di Indonesia. Hal ini dapat dilihat dari semakin banyak perusahaan industri yang menutup atau memindahkan usahanya ke negara lain, seperti ke Vietnam dan Tiongkok. ${ }^{9}$ Bahkan, ada kecenderungan mereka yang sudah melakukan investasi sejak lama di Indonesia meninggalkan Indonesia dan memindahkan investasinya ke negara lain. Bahkan dalam era globalisasi ekonomi sekarang ini, ketiga unsur tersebut manjadi kian bertambah penting, antara lain dengan berkembangnya mekanisme pasar. ${ }^{10}$

Pada dasarnya,kewajiban pemerintah dan/atau pemerintah daerah adalah menjamin kepastian dan keamanan berusaha bagi pelaksanaan penanaman modal. Untuk menjamin kepastian, dan keamanan itu perlu diatur kewenangan pemerintah,provinsi, dan kabupaten/kota dalam penyelenggaraan penanaman modal. ${ }^{11}$ Kepastian hukum ini meliputi ketentuan peraturan perundangundangan yang dalam banyak hal tidak jelas bahkan bertentangan dan juga mengenai pelaksanaan putusan pengadilan. Kesulitankesulitan tersebut dapat dikatakan merupakan kesulitan-kesulitan yang dihadapi oleh negara-negara berkembang yang mengundang penanaman modal asing untuk membantu pertumbuhan ekonominya. ${ }^{12}$

9 Ridwan Khairandy, 2006, 'Iklim Investasi dan Jaminan Kepastian Hukum dalam Era Otonomi Daerah," Jurnal Hukum Respublica Vol. 5 No. 2, hlm. 148.

10 C.F.G. Sunaryati Hartono, 1979, Beberapa Masalah Transnasional dalam Penanaman Modal Asing di Indonesia, (Bandung: PT. Bina Cipta), hlm. 56.

11 Grandnaldo Yohanes Tindangen, 2016, "Perlindungan Hukum Terhadap Investor Menurut Undang-Undang Nomor 25 Tahun 2007 Tentang Penanaman Modal," Lex Administratum, Vol. IV/No. 2, hlm.19.

12 Mochtar Kusumaatmadja, 1996, "Investasi di Indonesia dalam Kaitannya dengan Pelaksanaan Perjanjian Hasil Putaran Uruguay," Jurnal Hukum Ius Quia Iustum No.5 Vol. 3., hlm. 6.
Faktor kepastian hukum sangat berhubungan dengan masalah jaminan yang diberikan oleh pemerintah negara penerima modal kepada para investor asing sehingga para investor tersebut tidak merasa ragu untuk menanamkan modalnya. Terkait dengan hal tersebut, salah satu bentuk komitmen Pemerintah Indonesia untuk memberikan jaminan serta perlindungan kepada para investor asing adalah dengan menerbitkan UU Nomor 25 Tahun 2007 tentang Penanaman Modal. Dalam undang-undang tersebut terdapat beberapa ketentuan yang terkait dengan perlindungan terhadap investor asing, antara lain ketentuan mengenai pemberian perlakuan yang sama kepada semua investor (Pasal 6), ketentuan mengenai nasionalisasi dan kompensasi (Pasal 7), dan ketentuan mengenai pengalihan aset serta transfer dan repatriasi dalam valuta asing (Pasal 8 dan Pasal 9).

Membahas pelaksanaan beberapa ketentuan UU Penanaman Modal yang terkait dengan perlindungan terhadap investor asing atas risiko-risiko yang (mungkin) dihadap investor asing, khususnya risiko-risiko nonkomersial. Pasal 4 Ayat (2) Huruf a UU Penanaman Modal menyatakan bahwa dalam menetapkan kebijakan dasar penanaman modal, pemerintah memberi perlakuan yang sama bagi investor domestik dan investor asing. Selanjutnya, pada Huruf $b$ dikatakan bahwa pemerintah menjamin kepastian hukum, kepastian berusaha, dan keamanan berusaha bagi investor sejak proses pengurusan perizinan sampai dengan berakhirnya kegiatan penanaman modal.

Terkait dengan perlakuan yang sama bagi semua investor, Pasal 6 UU Penanaman Modal menyatakan, pemerintah memberikan perlakuan yang sama kepada semua investor yang berasal dari negara mana pun yang melakukan kegiatan penanaman modal di Indonesia sesuai dengan ketentuan peraturan perundang-undangan. Perlakuan yang sama tersebut tidak berlaku bagi investor dari suatu negara yang memperoleh hak istimewa berdasarkan perjanjian dengan Indonesia. Hak 
istimewa yang dimaksud, antara lain hak istimewa yang berkaitan dengan kesatuan kepabeanan, wilayah perdagangan bebas, pasar bersama, kesatuan moneter, kelembagaan yang sejenis, dan perjanjian antara Pemerintah Indonesia dan pemerintah asing yang bersifat bilateral, regional, atau multilateral yang berkaitan dengan hak istimewa tertentu dalam penyelenggaraan penanaman modal.

Pasal 6 UUPM tersebut adalah merupakan realisasi dari azas perlakuan yang sama dan tidak membedakan asal negara sebagaimana tersebut dalam Pasal 3 Ayat (1) huruf (d) UUPM. Pengaturan sudah tepat mengingat selama ini ada anggapan yang beredar dalam masyarakat bahwa terdapat perbedaan perlakuan yang signifikan untuk sesame investor baik antar investor dalam negeri dengan investor asing, terutama dengan adanya perlakuan bagi investor asing berupa tax holiday dan kelonggaran serta keringanan-keringanan pajak yang diberikan sehubungan dengan penanaman modal asing yang dilakukannya. ${ }^{13}$

Apa yang diatur dalam Pasal 6 ayat 2) UU Penanaman Modal adalah berkaitan dengan adanya sejumlah perjanjian internasional yang bersifat bilateral antara Pemerintah Indonesia dengan Pemerintah Asing dalam bentuk perjanjian jaminan Investasi (Investment Guarantie of Agreement, IGA) berkaitan dengan penanaman modal asing yang dilakukan oleh negara dan/atau warga negaranya berdasarkan UU Penanaman Modal yang mempunyai hak istimewa. $^{14}$

Selanjutnya, mengenai nasionalisasi dan kompensasi (Pasal 7 UU Penanaman Modal). Dikatakan bahwa pemerintah tidak akan melakukan tindakan nasionalisasi atau pengambilalihan hak kepemilikan investor,

\footnotetext{
13 Sjahril Effendy, 2014, "Perlindungan Hukum Terhadap Investor Asing Perusahaan Joint Venture Sektor Air Bersih di Kabupaten Deli Serdang (Studi Pada PT. Tirta Lyonnaise Medan)," Jurnal Mercatoria Vol 7/No 2, hlm.9.

14 Ibid.
}

kecuali dengan undang-undang. Dalam hal pemerintah melakukan tindakan nasionalisasi atau pengambilalihan hak kepemilikan, pemerintah akan memberikan kompensasi yang jumlahnya ditetapkan berdasarkan harga pasar. Jika di antara kedua belah pihak tidak tercapai kesepakatan tentang kompensasi atau ganti kerugian, maka penyelesaiannya dilakukan melalui arbitrase.

Apabila ketentuan mengenai nasionalisasi dan kompensasi tersebut diperhatikan, terutama kalimat "tidak akan melakukan tindakan nasionalisasi atau pengambilalihan", terlihat bahwa pada dasarnya Indonesia sudah mengurangi salah satu haknya sebagai negara yang berdaulat yang diakui oleh hukum internasional. Sejarah mencatat bahwa Indonesia pernah melakukan tindakan nasionalisasi sebagai sikap yang diambil pemerintah untuk memperbaiki kerja sama dengan negara-negara lain di dunia serta memperbaiki keadaan ekonomi yang kacau.

Oleh karena nasionalisasi merupakan tindakan yang diakui secara sah oleh hukum internasional, maka pada dasarnya bukan merupakan suatu kesalahan apabila suatu negara melakukan tindakan nasionalisasi dengan syarat harus memperhatikan ketentuan hukum yang berlaku, artinya harus sesuai dengan undang-undang yang berlaku. Nasionalisasi harus dilakukan dengan dasar yang kuat, dalam arti bukan hanya merupakan keinginan pemerintah semata-mata, tetapi harus berdasarkan alasan yang kuat dan sesuai dengan ketentuan-ketentuan yang sudah disepakti dalam kontrak penanaman modal. Selain itu, tindakan nasionalisasi yang dilakukan oleh satu negara harus sesuai dengan cara yang diakui oleh hukum internasional, antara lain tindakan nasionalisasi hanya dapat dilakukan oleh negara yang berdaulat serta tidak dilakukan secara diskriminatif terhadap orang asing saja atau orang asing dari negara tertentu saja.

Pengaturan masalah nasionalisasi dalam UU Penanaman Modal lebih dimaksudkan sebagai bukti itikad baik Pemerintah Indonesia untuk bekerja sama dengan negara 
lain di dunia. Dengan adanya ketentuan mengenai nasionalisasi, Pemerintah Indonesia telah secara sukarela mengurangi haknya untuk menasionalisasikan perusahaan asing, yaitu dengan memperketat syarat-syarat untuk melakukan nasionalisasi yang sudah dianggap sebagai hak setiap negara yang berdaulat oleh hukum internasional. Selain itu, menyerahkan penentuan jumlah, macam, dan cara pembayaran kompensasi kepada keputusan yang tercapai dalam perundingan antara Pemerintah Indonesia dengan penanam modal asing. Apabila tidak tercapai kesepakatan, maka dapat diselesaikan melalui forum arbitrase. ${ }^{15}$

Mengenai syarat dilakukannya nasionalisasi, selain harus berdasarkan undang-undang juga ada kewajiban untuk memberikan kompensasi yang jumlahnya ditetapkan berdasarkan harga pasar, yaitu harga yang ditentukan menurut cara yang digunakan secara internasional oleh penilai independen yang ditunjuk oleh para pihak. Apabila tidak ada kata sepakat antara pemerintah dan investor mengenai jumlah kompensasi, maka penyelesaiannya dilakukan melalui arbitrase. Hal ini menunjukkan adanya tanggung jawab pemerintah apabila terpaksa melakukan tindakan nasionalisasi.

Terkait dengan risiko nonkomersial, dalam UU Penanaman Modal juga diatur mengenai pengalihan aset serta hak transfer dan repatriasi dalam valuta asing (Pasal 8 dan Pasal 9). Investor dapat mengalihkan aset yang dimilikinya kepada pihak yang diinginkan sesuai dengan ketentuan peraturan perundang-undangan. Investor juga dapat melakukan transfer dan repatriasi dalam valuta asing. Transfer yang dimaksud adalah alih keuntungan dalam valuta/mata uang asli dari modal atas dasar nilai tukar ke negara asalnya, sedangkan repatriasi adalah kembalinya hak yang dimiliki investor dari negara yang pernah menjadi domisilinya

15 Adolf Warow dalam Hulman Panjaitan, 2003, "Hukum Penanaman Modal Asing" (Jakarta: IndoHill Co.), hlm. 81. menuju ke negara asal kewarganegaraannya. Hak transfer dan repatriasi tersebut mencakup modal, keuntungan, bunga bank, dividen, pendapatan lain, dan sebagainya.

Selain dalam peraturan perundangundangan, perlindungan terhadap investasi asing diberikan dalam perjanjian multilateral. Salah satunya perjanjian internasional tentang jaminan dalam penanaman modal (Konvensi MIGA). Walaupun telah ada perlindungan dalam UU Penanaman Modal dan perjanjian bilateral mengenai perlindungan terhadap penanaman modal, investor asing secara mandiri tetap berupaya agar terhindar dari kerugian yang mungkin timbul sebagai akibat political risks atau risiko-risiko yang bersifat nonkomersial, antara lain dilakukan dengan menjaminkan investasinya kepada MIGA. Pada dasarnya, MIGA memberikan jaminan terhadap apa yang dinamakan risiko-risiko non-komersial (non-commercial risiks), seperti risiko terhadap transfer moneter, tindakan nasionalisasi, pelanggaran kontrak, dan risiko yang terkait dengan perang atau gangguan keamanan.

\section{Implikasi Perlindungan Hukum terhadap Investor Asing bagi Negara}

Indonesia masih dinilai sebagai salah satu negara yang belum sepenuhnya mendukung kehadiran investasi asing. Di satu sisi, Indonesia sangat membutuhkan kehadiran investor asing untuk membawa modal masuk ke dalam negeri, baik dalam bentuk investasi langsung maupun investasi portofolio. Di sisi lain, banyak kendala investasi yang belum dibenahi secara komprehensif, khususnya dalam hal kepastian hukum. Salah satu hal yang dapat dilakukan adalah memberi perlindungan kepada investor asing, baik yang didasarkan pada ketentuan hukum nasional maupun hukum internasional. Keikutsertaan Indonesia dalam Konvensi MIGA, sedikit banyak akan turut mendorong peningkatan investasi asing di Indonesia.

Dalam situasi sekarang ini, peran investor asing sangat membantu. Pada saat ekspor 
dalam negeri mengalami kelesuan, pemerintah dapat mengandalkan investor asing sebagai salah satu pemasok devisa negara. Selain itu, investor asing dapat membantu dalam hal penyediaan dana untuk membiayai berbagai proyek pembangunan ekonomi maupun pembangunan sektor industri. Pada dasarnya beberapa alternatif yang dapat ditempuh untuk menahan atau menarik para investor asing untuk terus menanamkan modalnya di Indonesia adalah perlindungan yang diberikan pemerintah kepada investor asing, baik melalui peraturan perundang-undangan nasional maupun melalui instrumen hukum internasional. Komitmen Pemerintah Indonesia untuk melaksanakan ketentuan mengenai perlindungan atas investasi asing, baik yang diatur dalam UU Penanaman Modal maupun yang didasarkan pada perjanjian bilateral dan Konvensi MIGA telah memberikan kontribusi atau manfaat yang sangat berarti bagi kegiatan penanaman modal asing di Indonesia.

Menurut hasil penelitian (Reza Lainatul Rizky et al.:2016), secara parsial penanaman modal dalam negeri berpengaruh positif dan signifikan terhadap pertumbuhan ekonomi provinsi di Indonesia tahun 2010-2013. Hal ini berarti apabila nilai penanaman modal asing mengalami peningkatan maka pertumbuhan ekonomi juga akan meningkat karena memiliki pengaruh yang positif. ${ }^{16}$ Nilai penanaman modal dalam negeri 33 provinsi di Indonesia memiliki pengaruh yang positif dan signifikan terhadap pertumbuhan ekonomi di Indonesia karena didorong oleh beberapa hal yaitu yang pertama yaitu iklim investasi di Indonesia, infrastruktur di Indonesia, sumber daya alam melimpah, dan adanya pasar domesik. ${ }^{17}$ Dengan kata lain, adanya perlindungan hukum terhadap

16 Reza Lainatul Rizky, Grisvia Agustin, Imam Mukhlis, 2016, "Pengaruh Penanaman Modal Asing, Penanaman Modal Dalam Negeri dan Belanja Modal Terhadap Pertumbuhan Ekonomi Provinsi di Indonesia", Jurnal Ekonomi dan Studi Pembangunan, Vol. 8, No 1 (Maret), hlm. 14.

17 Ibid. investsor asing dapat meningkatkan pertumbuhan ekonomi Indonesia.

Adanya jaminan perlindungan terhadap investor asing atas risiko-risiko nonkomersial dalam kegiatan penanaman diharapkan menjadi salah satu faktor untuk menciptakan iklim investasi yang kondusif. Pada gilirannya, hal tersebut akan mendorong peningkatan kegiatan investasi asing di Indonesia. Jaminan perlindungan terhadap investor merupakan salah satu faktor pendukung peningkatan kegiatan penanaman modal asing di Indonesia dalam jangka panjang, khususnya pada era perdagangan bebas yang ditandai oleh persaingan yang semakin kompetitif.

Memasuki era perdagangan bebas dunia di bawah WTO, dengan adanya jaminan perlindungan terhadap investor atas risikorisiko nonkomersial diharapkan akan mendorong kegiatan perdagangan dan peningkatan perdagangan akan mendorong penanaman modal lebih lanjut. Pemerintah Indonesia dapat memanfaatkan keunggulan yang dimiliki perusahaan penanaman modal asing, khususnya yang berbentuk perusahaan multinasional. Hal ini dapat dilakukan dengan memberi kesempatan kepada perusahaan penanaman modal asing untuk mengekspor produknya ke luar negeri karena perdagangan antarperusahaan multinasional telah menjadi faktor utama penggerak ekspor impor dunia. Selain akan meningkatkan daya saing produk Indonesia di pasar internasional, sistem produksi dan distribusi internasional dalam perusahaan penanaman modal asing pada umumnya juga akan mendukung pasar domestik memiliki akses ke arus barang dan jasa dunia (sebuah pasar yang memiliki akses khusus).

Perusahaan penanaman modal asing juga dapat membuka pasar bagi perusahaan lokal yang berstatus sebagai usaha kecil dan menengah apabila perusahaan lokal tersebut memiliki akses kepada perusahaan penanaman modal asing. Apabila perusahaan lokal memiliki akses ke pasar internasional, maka perusahaan yang bersangkutan akan 
mampu menghadapi pesaing di pasar internasional. Pada gilirannya, dapat meningkatkan daya saing produk Indonesia di pasar internasional.

Dampak dari banyaknya investasi asing terhadap impor tidak begitu besar. Hal tersebut menunjukkan bahwa dalam jangka panjang, investasi asing hanya memberikan kontribusi yang kecil terhadap kinerja impor Indonesia artinya dalam jangka panjang besarnya nilai investasi asing yang masuk ke Indonesia tidak begitu memengaruhi besarnya nilai impor Indonesia. Hal tersebut mengindikasikan bahwa kinerja impor Indonesia cenderung dipengaruhi oleh faktorfaktor lain seperti pertumbuhan ekonomi, kondisi perekonomian internasional, nilai tukar,dan lain-lain. Selain itu, karena pada dasarnya impor barang modal merupakan barang yang bersifat tahan lama sehingga kenaikan impor yang disebabkan oleh masuknya investasi asing hanya akan berpengaruh pada periode-periode awal namun dalam jangka panjang pengaruhnya akan semakin kecil. ${ }^{18}$

Kegiatan penanaman modal yang dilakukan investor asing tidak hanya mendatangkan keuntungan bagi peningkatan volume perdagangan internasional Indonesia sebagai negara penerima modal, tetapi juga mendatangkan keuntungan bagi kegiatan perdagangan di negara asal investor. Dalam hal ini, dengan adanya kegiatan penanaman modal asing, maka berbagai produk teknologi yang ada di negara asal investor dapat dijual di Indonesia sebagai negara penerima modal. Teknologi berkembang melalui investasi asing sebagai channel transfer teknologi internasional. Dengan mendorong investasi asing, negara berkembang tidak hanya tergantung pada impor teknologi asing yang efisien, namun juga pada penciptaan penyebaran teknologi (technological

18 Suci Safitriani, 2014, "Perdagangan Internasional dan Foreign Direct Investment di Indonesia," Buletin Ilmiah Litbang Perdagangan, Vol.8/No.1 (Juli ), hlm.112. spillovers) bagi perusahaan-perusahaan lokal. ${ }^{19}$

\section{E. KESIMPULAN}

Perlindungan hukum terhadap penanaman modal asing dalam hukum nasional Indonesia diatur dalam UU Nomor 25 Tahun 2007 tentang Penanaman Modal. Undang-undang ini telah memberikan perlindungan yang memadai terhadap investor asing atas berbagai risiko termasuk risiko nonkomersial dalam penanaman modal asing di Indonesia. Hal ini terlihat dalam beberapa ketentuan undang-undang tersebut, antara lain melalui pengaturan hak investor asing terkait dengan beberapa hal (Pasal 6 sampai dengan Pasal 9), yaitu adanya jaminan perlakuan yang sama bagi semua investor serta jaminan atas tindakan nasionalisasi dan tindakantindakan pengambilalihan lainnya. Selain itu, jaminan untuk melakukan pengalihan aset serta transfer dan repatriasi dalam valuta asing untuk modal, keuntungan, dan beberapa hal lainnya. Adapun perlindungan dalam hukum internasional, yakni perlindungan atas resiko non komersial yang dijamin oleh MIGA.

Implikasi perlindungan hukum terhadap investor asing bagi kegiatan penanaman modal asing di Indonesia, antara lain dapat memberikan kontribusi atau manfaat yang sangat berarti bagi peningkatan kegiatan penanaman modal asing. Adanya jaminan perlindungan terhadap investor asing atas risiko-risiko nonkomersial dalam kegiatan penanaman diharapkan menjadi salah satu faktor untuk menciptakan iklim investasi yang kondusif. Pada gilirannya, hal tersebut akan mendorong peningkatan kegiatan investasi asing di Indonesia. Jaminan perlindungan terhadap investor merupakan salah satu faktor pendukung peningkatan kegiatan penanaman

19 Firdaus Jufrida, Mohd. Nur Syechalad, Muhammad Nasir, 2016, “Analisis Pengaruh Investasi Asing Langsung (FDI) dan Investasi Dalam Negeri terhadap Pertumbuhan Ekonomi Indonesia," Jurnal Perspektif Ekonomi Darussalam, Vol 2/No.1, (Maret), hlm.59. 
modal asing di Indonesia dalam jangka panjang, khususnya pada era perdagangan bebas yang ditandai oleh persaingan yang

\section{DAFTAR PUSTAKA}

Arief Sidharta, Filsafat Hukum Pancasila, Makalah, (Tidak dipublikasikan)

Bob Sugeng Hadiwinata, 2002, Politik Bisnis Internasional (Yogyakarta: Kanisius)

Budiono Kusumohamidjojo, 1999, Ketertiban Yang Adil: Problematik Filsafat Hukum, Grasindo, Jakarta

C.F.G. Hartono, Sunaryati., 1979, Beberapa Masalah Transnasional dalam Penanaman Modal Asing di Indonesia, (Bandung: PT. Bina Cipta).

Effendy, Sjahril., 2014, "Perlindungan Hukum Terhadap Investor Asing Perusahaan Joint Venture Sektor Air Bersih di Kabupaten Deli Serdang (Studi Pada PT. Tirta Lyonnaise Medan)," Jurnal Mercatoria Vol.7/No.2.

Hemmer, Hans-Rimbert et al., tanpa tahun, Negara Berkembang dalam Proses Globalisasi: Untung atau Buntung?.Jakarta: Konrad Adenauer Stiftung - Jakarta Office.

Indonesia, Undang-Undang Nomor 25 Tahun 2007 tentang Penanaman Modal.

Jufrida, Firdaus et al., 2016, “Analisis Pengaruh Investasi Asing Langsung (FDI) dan Investasi Dalam Negeri terhadap Pertumbuhan Ekonomi Indonesia," Jurnal Perspektif Ekonomi Darussalam, Vol 2/No.1.

Khairandy, Ridwan., 2006, "Iklim Investasi dan Jaminan Kepastian Hukum dalam Era Otonomi Daerah,"Jurnal Hukum Respublica Vol. 5 No. 2.

Kusumaatmadja, Mochtar, 1996, Investasi di Indonesia dalam Kaitannya dengan Pelaksanaan Perjanjian Hasil Putaran Uruguay, Jurnal Hukum Ius Quia Iustum No.5 Vol. 3.

O.Notohamidjojo, Makna Negara Hukum Bagi Pembaharuan Negara dan Wibawa Hukum Bagi Pembaharuan semakin kompetitif dan pertumbuhan ekonomi negara.

Masjarakat di Indonesia (Jakarta: Badan Penerbit Kristen, tanpa tahun terbit)

Panjaitan, Hulman., 2003, Hukum Penanaman Modal Asing (Jakarta: Indo-Hill Co.).

Rizky, Reza Lainatul et al.,2016, "Pengaruh Penanaman Modal Asing, Penanaman Modal Dalam Negeri dan Belanja Modal Terhadap Pertumbuhan Ekonomi Provinsi di Indonesia", Jurnal Ekonomi dan Studi Pembangunan, Vol. 8, No 1.

Safitriani, Suci., 2014, "Perdagangan Internasional dan Foreign Direct Investment di Indonesia," Buletin Ilmiah Litbang Perdagangan, Vol.8/No.1.

Salim HS dan Budi Sutrisno, 2008, Hukum Investasi di Indonesia (Jakarta: RajaGrafindo Persada,)

Tindangen, Grandnaldo Yohanes., 2016, "Perlindungan Hukum Terhadap Investor Menurut Undang-Undang Nomor 25 Tahun 2007 Tentang Penanaman Modal," Lex Administratum, Vol. IV/No. 2. 